\title{
Performance of young jack pine trees originating from two different branch angle traits under different intensities of competition
}

\author{
Guy R. Larocque* \\ Natural Resources Canada, Canadian Forest Service, Laurentian Forestry Centre, 1055 du P.E.P.S., \\ P.O. Box 3800, Sainte-Foy, Quebec, Canada G1V4C7
}

(Received 16 June 1999; accepted 5 June 2000)

\begin{abstract}
The performance of young jack pine (Pinus banksiana Lamb.) trees, originating from seed orchard trees of two different branch angle traits, was examined under different intensities of competition with morphological measures of crown development and growth efficiency measures. Seedlings were planted under a split-plot design at five initial spacings $-0.5 \mathrm{~m}, 0.75 \mathrm{~m}, 1.0 \mathrm{~m}, 1.5 \mathrm{~m}$ and $2.0 \mathrm{~m}$-, three blocks, two branching characteristics and four replicates. Relative growth rate for diameter at breast height (dbh) increased by nearly twofold from the closest to the largest spacing. Crown width, crown ratio, needle density ratio and leaf weight ratio decreased significantly with decrease in spacing, which indicated that the efficiency of jack pine crowns to occupy their growing space and the proportion of photosynthesizing biomass relative to respiring biomass were negatively affected by competition. Needle nitrogen concentration decreased with decrease in spacing and was significantly related to leaf weight ratio. Variation with tree size in the ratios of dbh increment to needle biomass and to needle nitrogen content indicated that small trees produced stemwood per unit of photosynthetic tissue and per unit of nitrogen more efficiently than large trees in the absence of severe competition and that this trend was gradually reversed as the intensity of competition increased. Branch angle trait did not constitute a significant advantage for crown development and stem growth.
\end{abstract}

competition / growth efficiency measures / branch angle / nitrogen

Résumé - Performance de jeunes pins gris issus de deux caractères différents d'angle des branches sous différentes intensités de compétition. Le développement de jeunes pins gris (Pinus banksiana Lamb.), issus d'arbres parents localisés dans un verger à graines et différenciés par deux caractères d'angle des branches, a été analysé sous différentes intensités de compétition avec des mesures morphologiques de développement des cimes et d'efficacité de croissance. Les semis ont été plantés selon un dispositif en parcelles divises à cinq niveaux d'espacement $(0,5 \mathrm{~m}, 0,75 \mathrm{~m}, 1,0 \mathrm{~m}, 1,5 \mathrm{~m}$ et 2,0 m), deux classes d'angle des branches, trois blocs et quatre répétitions. Le taux relatif de croissance en diamètre à hauteur de poitrine (dhp) a presque doublé de l'espacement le plus serré à l'espacement le plus large. La largeur de la cime, le rapport cime-hauteur et les rapports de densité et de masse des aiguilles ont diminué de façon significative avec une diminution de l'espacement initial. Ces résultats indiquent que l'efficacité des couronnes du pin gris à occuper leur espace de croissance et la proportion de tissu assurant la photosynthèse par rapport à la proportion de tissu qui respire a été affectée négativement par la compétition. La concentration en azote des aiguilles, qui a diminué avec une réduction de l'espacement, a été reliée de façon significative au rapport de masse des aiguilles. La variation, en fonction de la taille des arbres, des rapports de croissance en diamètre sur la biomasse foliaire et le contenu en azote des aiguilles indique que, en l'absence de compétition sévère, les petits arbres ont produit plus efficacement de la matière ligneuse par unité de tissu photosynthétique et d'azote que les gros arbres et que cette tendance s'est inversée à mesure que l'espacement diminuait. L'angle de branchaison des arbres ne s'est pas révélé présenter un avantage significatif pour le développement des cimes et la croissance des tiges.

compétition / mesures d'efficacité de croissance / angle des branches / azote

*Correspondence and reprints

Tel. 418648 5791; Fax. 418648 5849; e-mail: glarocque@cfl.forestry.ca 


\section{INTRODUCTION}

Jack pine (Pinus banksiana Lamb.) is harvested quite intensively in the boreal forest mainly for the production of pulp and paper. This probably explains why much effort has been devoted to study the productivity of seedlings and mature trees. For instance, several studies examined the effect of interspecific competition caused by shrubs and small lignified species on the growth of seedlings that were regenerated artificially or naturally following clearcutting or fire [e.g., 5, 32, 37, 40, 43, 61]. Other studies compared volume production under different initial stand densities and site qualities and analyzed the effect of thinning or fertilization treatments [e.g., 3, 20, 30, 34, 46, 52, 54]. Compared with other conifer species that compose the boreal forest such as white spruce (Picea glauca [Moench] Voss) or black spruce (Picea mariana [Mill.] B.S.P.), jack pine has been found to be very sensitive to competitive stress $[3,5,33,39$, 40].

Much information still needs to be acquired on the effect of competition at young ages for jack pine. In particular, there is a lack of information on the amplitude of competition in young stands that are tall enough to avoid above-ground competition from shrubs and small lignified species, but before self-thinning becomes too severe. Experimental designs to study systematically changes in growth, crown development and nutritional status under a relatively wide range of initial densities have seldom been used to analyze the development of young jack pine trees.

Jack pine is characterized by a high degree of plasticity [15]. Significant differences in growth patterns are related to crown characteristics $[2,41]$. In particular, branch angle is characterized by a relatively high degree of heritability and is closely related to wood quality [1, 35]. Differences in productivity can be expected among provenances characterized by different branch angles because this heritability trait influences the response of trees to light competition or stocking $[8,9]$. Despite the fact that some studies suggested weak correlations between branch angle and height growth traits for different jack pine provenances [e.g., 1, 2, 35], they have not determined if branch angle inheritance constitutes a significant advantage for crown development and stem growth as crowns interact under different intensities of competition.

The objective of the present study was to evaluate the sensitivity of young jack pine trees, which originated from two branch angle traits, to various intensities of intraspecific competition. Thus, it was possible to estimate if branch angle trait resulted in a significant advantage for wood production. The extent to which crowns and foliage responded in terms of space occupancy and efficiency to occupy growing space was examined.

\section{MATERIALS AND METHODS}

\subsection{Study site}

The study took place at the research forest of the Petawawa National Forestry Institute (lat. $46^{\circ} 0^{\prime} \mathrm{N}$; long. $77^{\circ} 26^{\prime} \mathrm{W}$ ) on a site with a gentle slope that was clearcut in the winter of 1982-1983. Soil samples collected around the study site indicated that the material was homogeneous and consisted mostly of very coarse sand. A glyphosphate herbicide (Roundup) was applied in 1984 and 1985 to control the establishment of shrubs and woody non-commercial species. As the presence of shrubs and woody non-commercial species never became a problem in subsequent years, no further extensive control treatment was applied.

Seeds were collected in 1985 on jack pine trees located at the Spoor Lake seed production site of the Ontario Ministry of Natural Resources in the northeastern section of Algonquin Park. To be used for seed sources for the present study, trees had to be clear of any sign of insect or disease damage and the form of their stem had to be straight. Following this first selection, trees were classified into two major groups: (1) acute branch angle trees with branch angles between $25^{\circ}$ and $30^{\circ}$ and wide branch angle trees with branch angles between $60^{\circ}$ and $70^{\circ}$. Seeds were extracted for $16 \mathrm{~h}$ at $57^{\circ} \mathrm{C}$ dry bulb and $35-38^{\circ} \mathrm{C}$ wet bulb. Prior to storage, their moisture content was reduced to $5-8 \%$ in a conditioner at $24{ }^{\circ} \mathrm{C}$ dry bulb and $17^{\circ} \mathrm{C}$ wet bulb for $16 \mathrm{~h}$. Then, they were sown in Hillson's Spencer-Lemaire containers with a mixture of peat and vermiculite (3:1) in a greenhouse. After germination, seedlings were grown in the greenhouse for 2 months.

Seedlings were planted early in the 1986 growing season. The experimental design consisted of a split-plot design with three blocks, five spacings $-0.5 \times 0.5 \mathrm{~m}$, $0.75 \times 0.75 \mathrm{~m}, 1.0 \times 1.0 \mathrm{~m}, 1.5 \times 1.5 \mathrm{~m}$ and $2.0 \times 2.0 \mathrm{~m}-$, two branching characteristics - acute and wide branch angles -, and four replicates. Each experimental unit contained a sample plot with 25 trees surrounded by three rows acting as a buffer zone. In 1990, branch angle, which was defined as the angle between the trunk vertical line and the lower part of the branch at the insertion point of the branch, was measured on one branch selected at random on the 1989 whorl of 1282 trees located within two replicates of each combination of two blocks, five spacings and two branching characteristics. Every tree within all the sample plots was measured in diameter at breast height (dbh) and height in the fall of 1990 and 1991. 


\subsection{Data collection and analyses}

An experimental unit within each block, spacing and branch type was selected in 1990 and 1991 for destructive measurements. Within each sample plot selected, three trees were selected by stratified random sampling based on tree size distribution for detailed measurements: dbh, total height, and crown length and width (mean of two perpendicular measures). Then, trees were cut at the root collar level, branches were separated from the stems, and stems were cut off in small pieces for laboratory analyses. The first step consisted in determining the biomass of stems, branches and needles. Because of the large amounts of material collected, a sub-sampling procedure was adopted. First, the fresh mass of the entire stem and of all the branches was determined. Then, pieces from different sections of the stem and branches from different sections of the crown representing about $20 \%$ of the tree were collected and needles were extracted from branches. These samples were weighed and oven-dried at $70^{\circ} \mathrm{C}$ until no change in mass was detected, which took between 2 and 3 days. The ratios of dry to fresh mass for both the stems and branches and of needles to branches that were determined for each tree were multiplied by the total fresh mass to derive the total dry mass.

The biomass samples that were dried were also used for nutrient analyses at the individual tree level. For each tree, the stem, branches and needles were ground separately and thoroughly mixed, and subsamples were taken for chemical analyses. Nitrogen content was determined by the Kjeldahl procedure following the methodology described by Kalra and Maynard [21].

\subsection{Growth analyses}

Morphological measures of crown development and measures of performance or efficiency as described by Brand [5], Hunt [18, 19] and Margolis and Brand [36] were derived from the growth, crown and nutrient data obtained during the two successive measurements and harvests (table I). Morphological measures of crown development were derived from absolute measures to evaluate the ability of crowns to occupy their growing space. Crown ratio (CR), which is also considered as a measure of vigor, is related to the photosynthetic capacity of a tree [11, 59]. Crown shape ratio (CSR), also known as the crown fullness ratio, provides a measure of the ability of crowns to intercept solar radiation $[23,25$, 48, 63]. According to Harper [17] and Kuuluvainen and Pukkala [26], the rate of change in this ratio is closely related to the intensity of self-thinning. Needle density ratio (NDR) is similar in concept to leaf area index in that it provides a measure of leafiness $[18,19]$. However, as the objective of the present study was to highlight the effect of competition on individual trees, this ratio was computed to derive a leafiness index based on the horizontal area occupied by individual crowns. Leaf weight ratio (LWR) is considered as an index of "productive investment" by Hunt [19] as it estimates the proportion of photosynthesizing biomass relative to respiring biomass.

Traditionally, tree and stand growth have been quantified by deriving measures based on cumulative growth or the rate of change in stem dimensions. These absolute measures indicated that the growth of stems and crowns and the amount of foliage decreased as the intensity of competition increased. As they are a function of tree size, these absolute measures simply provided a means to evaluate the importance of competition, not to draw inferences on its effect or to determine how individual trees respond to competition, which are critical elements to examine [16]. For these reasons, a measure of growth efficiency or vigor such as relative growth rate (RGR) (table I), which is considered as a measure of the productive capacity of a plant [12], has been suggested as an alternative to absolute measures that could provide an adequate evaluation of the competitive status of trees and stands $[10,13,14,49]$.

Measures of growth efficiency based upon crown development and nutrient uptake rate were computed using Hunt's $[18,19]$ equations for unit leaf rate (ULR) and specific utilization rate (SUR) (table I). However, as the measure of efficiency based on crown development used in the present study was based on needle biomass instead of needle area, it will be designed as foliage productive capacity (FPC). Based upon the methodology of Waring et al. [64, 65] and Norgren [45], allometric equations were derived to estimate needle biomass and nitrogen content of single trees for the computation of FPC and SUR.

For 1990 data, the following equations were derived:

Needle biomass $(\mathrm{g})=240.12447 \times \mathrm{dbh} \times$ spacing $(1)$

$$
R^{2}=0.95 ; S E_{\mathrm{E}}=162.559
$$

Tree nitrogen content $(\mathrm{mg})=$ $4878.4539 \times \mathrm{dbh} \times$ spacing

$$
R^{2}=0.96 ; S E_{\mathrm{E}}=3145.993
$$

For 1991 data, the following equations were derived:

$$
\begin{aligned}
& \text { Needle biomass }(\mathrm{g})=35.84339 \times \mathrm{dbh}^{2} \times \text { spacing } \\
& \qquad R^{2}=0.95 ; S E_{\mathrm{E}}=161.99862 \\
& \text { Tree nitrogen content }(\mathrm{mg})= \\
& 919.95434 \times \mathrm{dbh}^{2} \times \text { spacing } \\
& R^{2}=0.95 ; S E_{\mathrm{E}}=4026.763
\end{aligned}
$$


Table I. Summary of growth efficiency measures derived in the present study. For the computation of crown shape ratio, crown width is the average of two perpendicular measures at the base of the crown. $W_{2}$ and $W_{1}=$ diameter at breast height (dbh) or stem height at ages $T_{2}$ and $T_{1} ; D_{1}$ and $D_{2}=$ dbh at ages $T_{2}$ and $T_{1} ; F_{2}$ and $F_{1}=$ needle biomass at ages $T_{2}$ and $T_{1} ; N_{2}$ and $N_{1}=$ tree nitrogen content at ages $T_{2}$ and $T_{1}$.

\begin{tabular}{lcc}
\hline Name & Abbreviation & Definition \\
\hline \multicolumn{1}{c}{ Morphological measures of crown development } \\
Crown ratio & CR & $\frac{\text { Crownlength }}{\text { Stemlength }}$ \\
Crown shape ratio & CSR & $\frac{\text { Crown width }}{\text { Crownlength }}$ \\
Needle density ratio & NDR & $\frac{\text { Needle biomass }}{\text { Crownprojection }}$ \\
Leaf weight ratio & LWR & $\frac{\text { Needle biomass }}{\text { Total treebiomass }}$ \\
Relative growth rate & RGR & $\frac{\left(\ln W_{2}-\ln W_{1}\right)}{\left(T_{2}-T_{1}\right)}$ \\
Foliage productive capacity & FPC & $\frac{\mathrm{D}_{2}-\mathrm{D}_{1} \frac{\ln \left(F_{2}\right)-\ln \left(F_{1}\right)}{T_{2}-T_{1}}}{F_{2}-F_{1}}$ \\
& & $\frac{\mathrm{D}_{2}-\mathrm{D}_{1}}{T_{2}-T_{1}} \frac{\ln \left(N_{2}\right)-\ln \left(N_{1}\right)}{N_{2}-N_{1}}$ \\
\hline Specific utilization rate & SUR efficiency \\
\hline & &
\end{tabular}

Based on the studies by Ford [13, 14], Perry [47] and Larocque and Marshall [27, 29], RGR, FPC and SUR were used to evaluate the competitive status of the stands by examining their distribution with tree size. Perry [47] and Larocque and Marshall [27] observed three different relationships between RGR and tree sizes in Douglas-fir (Pseudotsuga menziesii (Mirb.) Franco) and red pine (Pinus resinosa Ait.) stands, respectively: absence of severe competition when the distribution of RGR with tree size is negative, initiation of competition-induced mortality when the distribution of RGR with tree size is flat, and intense competition when RGR increases with tree size. Similar patterns were also obtained by Schmitt et al. [55] for Impatiens capensis and by Cannell et al. [7] for Sitka spruce (Picea sitchensis (Bong.) Carr.) and lodgepole pine (Pinus contorta Dougl.). Reed et al. [50] concluded that the decrease in height RGR with increase in tree height in young red pine stands indicated that competition was not occurring among trees.
In the present study, it was examined if the distributions of FPC and SUR with tree size were similar to the distribution of RGR. Both FPC and SUR, which are similar in concept to RGR, were expected to provide better indication of the competitive status of stands than RGR because they allow a more direct examination of the ability of plants to exploit resources.

\subsection{Statistical analyses}

As previously mentioned, the experimental design consisted of a split-plot design. The following ANOVA model was computed using the GLM procedure in SAS [53]:

$$
\begin{aligned}
y_{i j k l}= & \mu+\beta_{i}+\tau_{j}+\varphi_{k}+\beta \tau_{i j}+\beta \varphi_{i k}+\tau \varphi_{j k} \\
& +\beta \tau \varphi_{i j k}+\rho(\beta \tau)_{l i j}+\mathrm{e}_{i j k l}
\end{aligned}
$$

where $y$ represents the dependent variable, $\mu$ the overall mean effect, $\beta$ the block effect, $\tau$ the spacing effect, $\varphi$ the branching characteristic effect, $\rho$ the subplot effect within block and spacing, and $e$ the residual error. The following orthogonal contrasts were defined: $4-1-1-1-1$ to compare the $0.5 \mathrm{~m}$ spacing against the $0.75,1.0,1.5$ and $2.0 \mathrm{~m}$ spacings, $01-100$ to compare the $0.75 \mathrm{~m}$ spacing against the $1.0 \mathrm{~m}$ spacing, $011-1-1$ to compare the 0.75 and $1.0 \mathrm{~m}$ spacings against the 1.5 and $2.0 \mathrm{~m}$ spacings, and $0001-1$ to compare the $1.5 \mathrm{~m}$ spacing against the $2.0 \mathrm{~m}$ spacing.

Linear regression analysis was undertaken to evaluate the degree of dependence of the needle density ratio on crown shape ratio and of leaf weight ratio on crown ratio and needle nitrogen concentration.

\section{RESULTS}

\subsection{Branch angle}

There was substantial variation in branch angles within each branch angle type (figure 1). For acute branch angle type, the majority of the trees had branch angles between $50^{\circ}$ and $65^{\circ}$. About $12 \%$ of the trees had branch angles less than or equal to $45^{\circ}$. For wide branch angle type, the majority of trees had branch angles between $50^{\circ}$ and $70^{\circ}$, and about $10 \%$ of the trees had branch angles equal to or greater than $75^{\circ}$. Even though the percentages of trees in both branch angle types overlapped in the branch angle classes from $45^{\circ}$ to $70^{\circ}$, the percentages were higher for acute branch angle type in the branch angle classes between $45^{\circ}$ and $55^{\circ}$ and higher for wide branch angle type between $60^{\circ}$ and $70^{\circ}$. Average values were $55^{\circ} \pm 7.39$ and $63^{\circ} \pm 8.60$ for acute and 


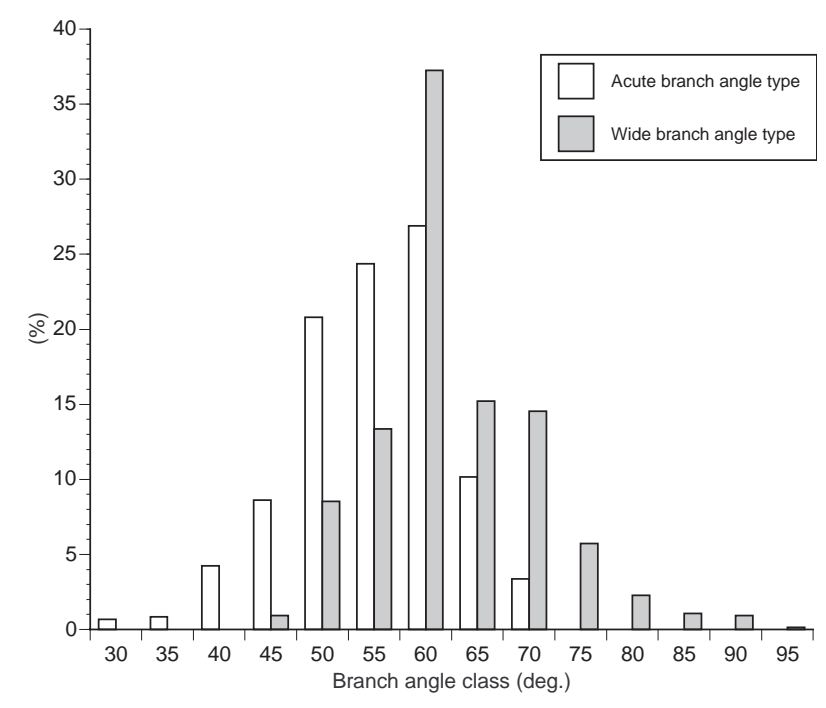

Figure 1. Proportions of trees in different acute and wide branch angle classes, as measured within two replicates of each combination of two blocks, five spacings and two branch angle traits.

wide branch angle types, respectively, and differed significantly $(P<0.01)$.

\subsection{Stem growth}

As far as cumulative growth in dbh and height was concerned, branch angle type was not statistically significant in 1990 and 1991 (figure 2, table II). In 1990, average dbh did not vary significantly among the four largest spacings. Only average dbh of the $0.5 \mathrm{~m}$ spacing was significantly lower than the mean of the $0.75,1.0$ and $1.5 \mathrm{~m}$ spacings. More significant differences were obtained in 1991: average dbh increased significantly with increase in spacing up to the $1.5 \mathrm{~m}$ spacing irrespective of branch angle type. Cumulative height did not differ significantly among spacings in both years.

Significant differences were obtained for dbh RGR between the $0.5 \mathrm{~m}$ and the means of the $0.75,1.0$ and $1.5 \mathrm{~m}$ spacings, and between the means of the 0.75 and $1.0 \mathrm{~m}$ spacings and the means of the 1.5 and $2.0 \mathrm{~m}$ spacings. The general trend was an increase in RGR with increase in spacing. Even though height RGR of the $0.5 \mathrm{~m}$ spacing differed significantly from the average of the $0.75,1.0$ and $1.5 \mathrm{~m}$ spacings, the difference was not very pronounced compared with the differences obtained for dbh RGR. Branch angle type was statistically significant only for height RGR. However, when branch angle types are compared for individual spacings, height RGR of the wide branch angle type was only slightly greater than that of the acute branch angle type.

\subsection{Crown development}

Differences among spacings were relatively more pronounced for crown development parameters than for stem development, particularly for crown width and the needle density ratio (figure 3, table III). Significant differences were obtained both in 1990 and 1991 for crown width. The general trend was an increase in crown width with increase in spacing. Both in 1990 and 1991, not only the $0.5 \mathrm{~m}$ spacing differed significantly from the mean of the $0.75,1.0$ and $1.5 \mathrm{~m}$ spacings, but also the mean of the 0.75 and $1.0 \mathrm{~m}$ spacings differed from the mean of the 1.5 and $2.0 \mathrm{~m}$ spacings. Even though the same contrasts were significant in both years, differences among spacings were greater in 1991 than in 1990 (figure 3). Crown overlap occurred only in 1991 within the $0.5 \mathrm{~m}$ spacing. Branch angle type was not significant for both years. For crown ratio in 1990, a significant difference was obtained only between the $0.5 \mathrm{~m}$ spacing and the mean of the $0.75 \mathrm{~m}, 1.0 \mathrm{~m}$ and $1.5 \mathrm{~m}$ spacings. In 1991, significant differences were obtained among all spacings, except between the $1.5 \mathrm{~m}$ and $2.0 \mathrm{~m}$ spacings. Branch angle type was not significant for both years.

Significant differences were obtained in both years for NDR (figure 3, table III). In 1990, the $0.5 \mathrm{~m}$ spacing was significantly lower than the mean of the $0.75 \mathrm{~m}, 1.0 \mathrm{~m}$ and $1.5 \mathrm{~m}$ spacings, as well as the mean of the 0.75 and $1.0 \mathrm{~m}$ spacings relative to the mean of the $1.5 \mathrm{~m}$ and $2.0 \mathrm{~m}$ spacings. Similarly to crown width and crown ratio, differences among spacings accentuated the year after such that only the $1.5 \mathrm{~m}$ and $2.0 \mathrm{~m}$ spacings did not differ significantly. Differences among spacings for LWR in 1990 were relatively less pronounced than those for NDR, as only the $0.5 \mathrm{~m}$ spacing differed significantly from the mean of the $0.75 \mathrm{~m}, 1.0 \mathrm{~m}$ and $1.5 \mathrm{~m}$ spacings (figure 3, table III). In 1991, LWR decreased substantially and significant differences were obtained between the $0.5 \mathrm{~m}$ spacing and the mean of the $0.75 \mathrm{~m}, 1.0 \mathrm{~m}$ and $1.5 \mathrm{~m}$ spacings and between the mean of the $0.75 \mathrm{~m}$ and $1.0 \mathrm{~m}$ spacings and the mean of the $1.5 \mathrm{~m}$ and $2.0 \mathrm{~m}$ spacings.

The linear regression equations for NDR were highly significant for both branch types, as $66 \%$ and $72 \%$ of the variation in NDR were explained by the regression on CSR, spacing and year, respectively (table $I V$ ). For both equations, spacing made the greatest relative contribution to the regression: the greater the spacing, the greater the NDR. The negative coefficients indicate that the density of needles decreased with increase in CSR and age. 

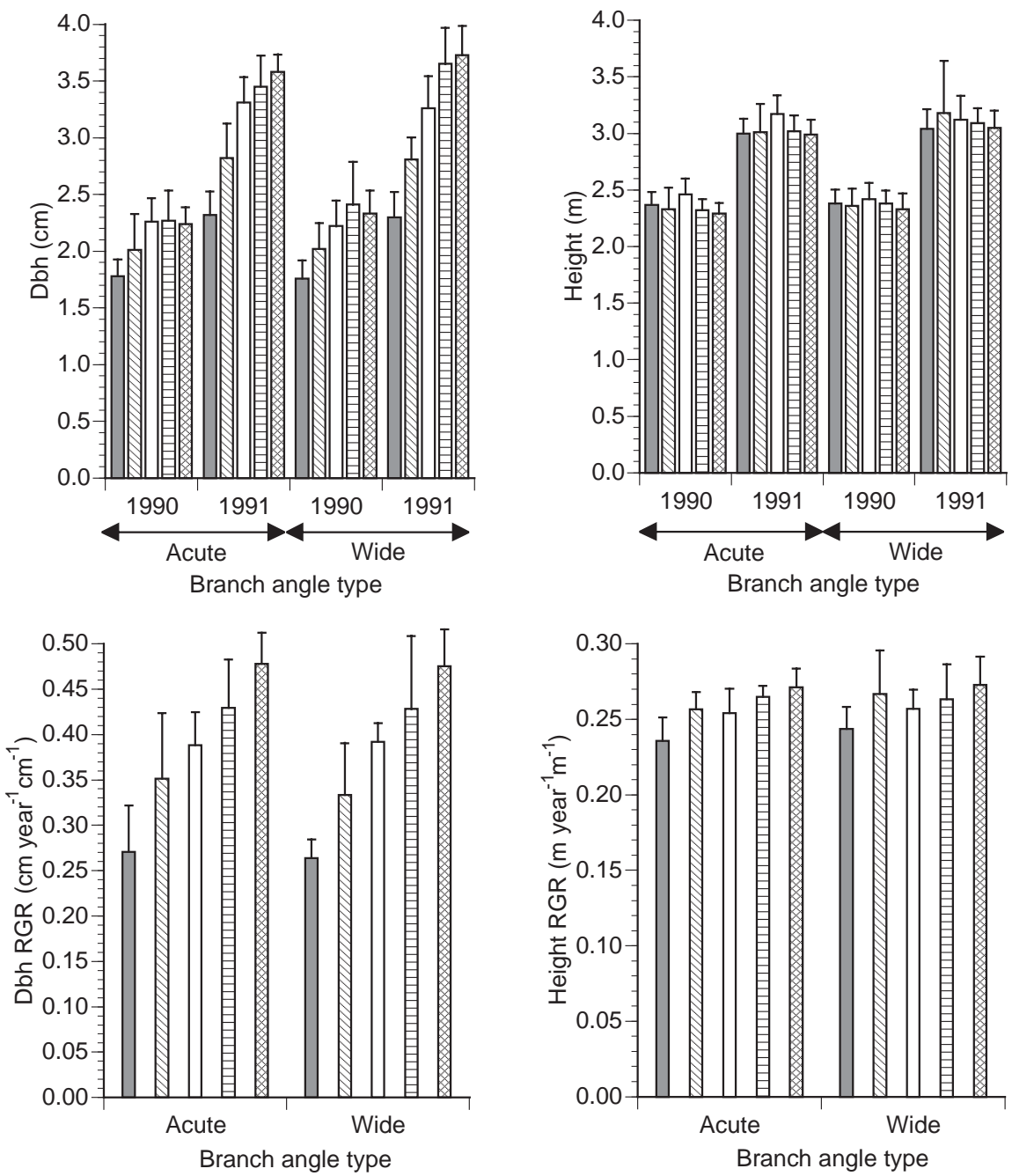

Spacing

$$
\square 0.5 \mathrm{~m} \quad 0.75 \mathrm{~m} \square 1.0 \mathrm{~m} \quad \text { 回 } 1.5 \mathrm{~m} \quad 2.0 \mathrm{~m}
$$

Figure 2. Growth differences for cumulative dbh and height and RGR obtained from measurement of all the trees at the end of two successive growing seasons. (Error bars represent standard deviations).

Table II. ANOVA $p$-values for cumulative growth and RGR for dbh and height.

\begin{tabular}{|c|c|c|c|c|c|c|}
\hline \multirow[t]{2}{*}{ Source of variation } & \multicolumn{2}{|c|}{ Dbh } & \multicolumn{2}{|c|}{ Height } & \multirow[b]{2}{*}{ Dbh RGR } & \multirow[b]{2}{*}{ Height RGR } \\
\hline & 1990 & 1991 & 1990 & 1991 & & \\
\hline Spacing & $<0.01$ & $<0.01$ & 0.654 & 0.878 & $<0.01$ & 0.044 \\
\hline Branch angle type & 0.306 & 0.079 & 0.435 & 0.152 & 0.570 & 0.028 \\
\hline Spacing $\times$ branch angle type & 0.443 & 0.086 & 0.645 & 0.370 & 0.902 & 0.105 \\
\hline \multicolumn{7}{|l|}{ Contrasts } \\
\hline 0.5 vs. $0.75,1.0,1.5$ & $<0.01$ & $<0.01$ & - & - & $<0.01$ & $<0.01$ \\
\hline 0.75 vs. 1.0 & 0.214 & 0.013 & - & - & 0.144 & 0.494 \\
\hline $0.75,1.0$ vs. $1.5,2.0$ & 0.143 & 0.007 & - & - & $<0.01$ & 0.156 \\
\hline 1.5 vs. 2.0 & 0.753 & 0.489 & - & - & 0.145 & 0.382 \\
\hline
\end{tabular}



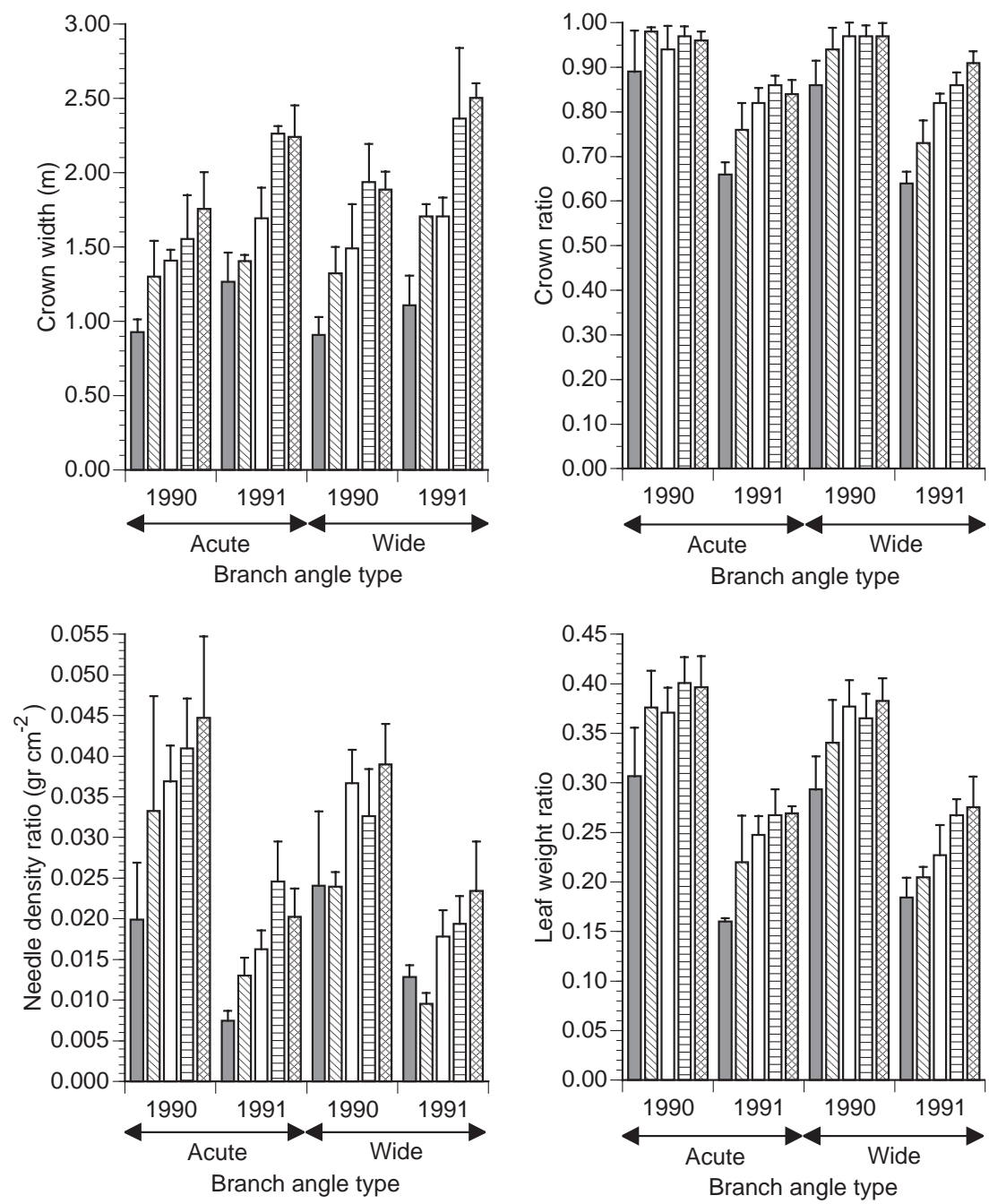

Spacing

$\square 0.5 \mathrm{~m}$ 四 $0.75 \mathrm{~m} \square 1.0 \mathrm{~m}$ 目 $1.5 \mathrm{~m}$ 图 $2.0 \mathrm{~m}$

Figure 3. Mean values for crown width, crown ratio, needle density ratio and leaf weight ratio for both branch angle types measured on sample trees harvested at the end of two growing seasons. (Error bars represent standard deviations).

Table III. ANOVA p-values for crown width and morphological measures of crown development.

\begin{tabular}{|c|c|c|c|c|c|c|c|c|}
\hline \multirow{2}{*}{ Source of variation } & \multicolumn{2}{|c|}{ Crown width } & \multicolumn{2}{|c|}{ Crown ratio } & \multicolumn{2}{|c|}{$\begin{array}{l}\text { Needle density } \\
\text { ratio }\end{array}$} & \multicolumn{2}{|c|}{$\begin{array}{l}\text { Leaf weight } \\
\text { ratio }\end{array}$} \\
\hline & 1990 & 1991 & 1990 & 1991 & 1990 & 1991 & 1990 & 1991 \\
\hline Spacing & $<0.01$ & $<0.01$ & $<0.01$ & $<0.01$ & $<0.01$ & $<0.01$ & $<0.01$ & $<0.01$ \\
\hline Branch angle type & 0.145 & 0.244 & 0.617 & 0.716 & 0.186 & 0.725 & 0.150 & 0.912 \\
\hline Spacing $\times$ branch angle type & 0.541 & 0.446 & 0.628 & 0.265 & 0.527 & 0.092 & 0.802 & 0.433 \\
\hline \multicolumn{9}{|l|}{ Contrasts } \\
\hline 0.5 vs. $0.75,1.0,1.5$ & $<0.01$ & $<0.01$ & $<0.01$ & $<0.01$ & $<0.01$ & $<0.01$ & $<0.01$ & $<0.01$ \\
\hline 0.75 vs. 1.0 & 0.281 & 0.326 & 0.792 & $<0.01$ & 0.083 & 0.016 & 0.429 & 0.106 \\
\hline $0.75,1.0$ vs. $1.5,2.0$ & $<0.01$ & $<0.01$ & 0.613 & $<0.01$ & 0.049 & $<0.01$ & 0.158 & $<0.01$ \\
\hline 1.5 vs. 2.0 & 0.546 & 0.646 & 0.992 & 0.59 & 0.272 & 0.934 & 0.740 & 0.704 \\
\hline
\end{tabular}


Table IV. Coefficients and statistics for linear regression equations relating needle density ratio (NDR) to crown shape ratio (CSR), spacing and year.

\begin{tabular}{|c|c|c|c|c|c|c|c|}
\hline Branch angle type & Intercept & CSR & Spacing & Year & $R^{2}$ & $S E_{\mathrm{E}}$ & $p$ \\
\hline Acute & 25.8121 & $\begin{array}{l}-0.03754 \\
(-0.481)^{\mathrm{a}}\end{array}$ & $\begin{array}{c}0.01838 \\
(0.757)\end{array}$ & $\begin{array}{c}-0.01295 \\
(-0.487)\end{array}$ & 0.66 & 0.00597 & $<0.01$ \\
\hline Wide & 16.0752 & $\begin{array}{c}-0.04298 \\
(-0.668)\end{array}$ & $\begin{array}{c}0.01870 \\
(0.913)\end{array}$ & $\begin{array}{c}-0.00806 \\
(-0.364)\end{array}$ & 0.72 & 0.00796 & $<0.01$ \\
\hline
\end{tabular}

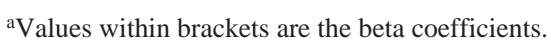

$R^{2}$, coefficient of determination; $S E_{\mathrm{E}}$, standard error of estimate; $p$, regression ANOVA $p$-values.
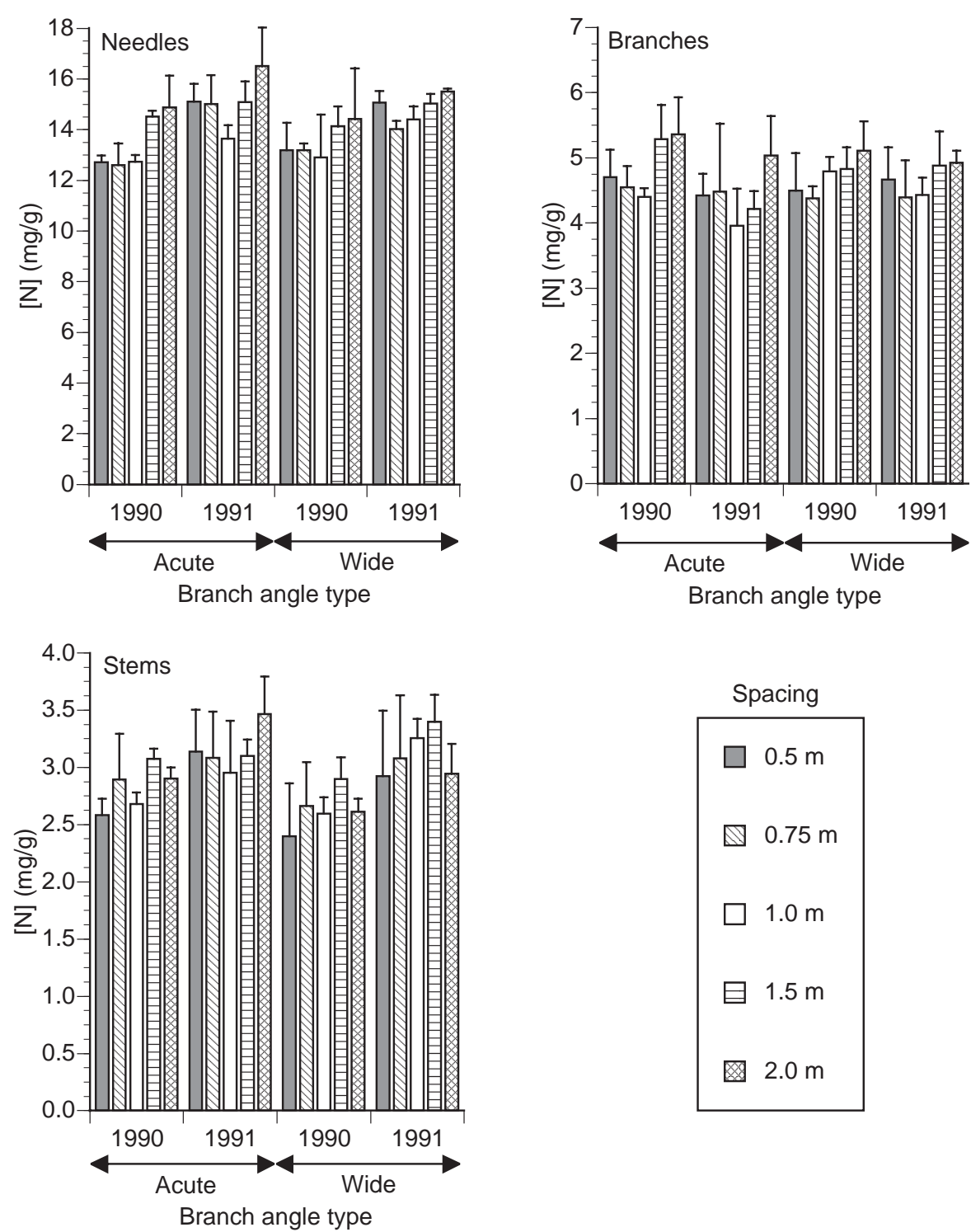

Figure 4. Mean nitrogen concentrations in needles, branches and stems for each brat
the end of two successive growing seasons (error bars represent standard deviations). 
Table V. ANOVA $p$-values for nitrogen concentrations in needles, branches and stems.

\begin{tabular}{|c|c|c|c|c|c|c|}
\hline \multirow[t]{2}{*}{ Source of variation } & \multicolumn{2}{|c|}{ Needles } & \multicolumn{2}{|c|}{ Branches } & \multicolumn{2}{|c|}{ Stems } \\
\hline & 1990 & 1991 & 1990 & 1991 & 1990 & 1991 \\
\hline Spacing & 0.017 & $<0.01$ & $<0.01$ & 0.103 & 0.054 & 0.811 \\
\hline Branch angle type & 0.845 & 0.457 & 0.237 & 0.134 & 0.062 & 0.935 \\
\hline Spacing $\times$ branch angle type & 0.870 & 0.309 & 0.229 & 0.632 & 0.972 & 0.285 \\
\hline \multicolumn{7}{|l|}{ Contrasts } \\
\hline 0.5 vs. $0.75,1.0,1.5$ & 0.161 & 0.560 & 0.109 & - & 0.024 & - \\
\hline 0.75 vs. 1.0 & 0.912 & 0.367 & 0.461 & - & 0.362 & - \\
\hline $0.75,1.0$ vs. $1.5,2.0$ & 0.002 & $<0.01$ & $<0.01$ & - & 0.147 & - \\
\hline 1.5 vs. 2.0 & 0.612 & 0.444 & 0.341 & - & 0.159 & - \\
\hline
\end{tabular}

However, the relative contribution of CSR was greater for wide branch angle trees than for acute branch angle trees.

\subsection{Nutrients}

Branch angle type was not significant for $\mathrm{N}$ concentrations in needles, branches and stems in both years (table V). In 1990, significantly greater $\mathrm{N}$ concentrations for needles and branches were obtained in the $1.5 \mathrm{~m}$ and $2.0 \mathrm{~m}$ spacings relative to the $0.75 \mathrm{~m}$ and $1.0 \mathrm{~m}$ spacings (figure 4, table $V$ ). The same pattern was obtained for needles in 1991 . For stems, only the $0.5 \mathrm{~m}$ spacing differed significantly from the mean of the $0.75 \mathrm{~m}, 1.0 \mathrm{~m}$ and $1.5 \mathrm{~m}$ spacings. In 1991, no significant difference was obtained for branches and stems.

Highly significant regression equations of LWR as a function of $\mathrm{CR}$ and needle $\mathrm{N}$ concentration were obtained for both branch angle types (table VI). Crown ratio made a much greater relative contribution than needle $\mathrm{N}$ concentration.

\subsection{Growth efficiency variation with tree size}

For conciseness, the distributions of dbh RGR, FPC and SUR with dbh are illustrated only for wide branch angle trees in block 1 (figures 5 and 6). Despite fluctuations, RGR distribution was relatively flat for the $0.5 \mathrm{~m}$ and $0.75 \mathrm{~m}$ spacings, while there was a pattern of decrease in RGR with increase in dbh in the $1.0 \mathrm{~m}, 1.5 \mathrm{~m}$ and $2.0 \mathrm{~m}$ spacings (figure 5). FPC and SUR decreased with increase in dbh within the five spacings (figure 6). However, the decrease was more pronounced within the $1.0 \mathrm{~m}, 1.5 \mathrm{~m}$ and $2.0 \mathrm{~m}$ spacings than within the $0.5 \mathrm{~m}$ and $0.75 \mathrm{~m}$ spacings.

\section{DISCUSSION}

\subsection{Branch angle}

Even though both branch angle types originated from trees with different branch angle characteristics and showed significant differences in mean branch angle, this heritability trait did not result in a significant advantage for crown development and stem growth under competition, as indicated by the lack of statistical significance for stem growth and crown variables. Two reasons may explain these results. Assuming that wide branch angle trees could constitute a competitive advantage because of greater crown spread, the increase in the amount of solar radiation that needles could receive did

Table VI. Coefficients and statistics for linear regression equations relating leaf weight ratio (LWR) to crown ratio (CR) and needle nitrogen concentration.

\begin{tabular}{|c|c|c|c|c|c|}
\hline Branch angle type & Crown ratio & Needle N concentration & $R^{2}$ & $S E_{\mathrm{E}}$ & $p$ \\
\hline Acute & $\begin{array}{l}0.49834 \\
(1.381)^{\mathrm{a}}\end{array}$ & $\begin{array}{l}-0.00904 \\
(-0.4078)\end{array}$ & 0.97 & 0.0574 & $<0.01$ \\
\hline Wide & $\begin{array}{c}0.4685 \\
(1.3564)\end{array}$ & $\begin{array}{l}-0.00795 \\
(-0.3793)\end{array}$ & 0.97 & 0.0519 & $<0.01$ \\
\hline
\end{tabular}

${ }^{a}$ Values within brackets are the beta coefficients.

$R^{2}$, coefficient of determination; $S E_{\mathrm{E}}$, standard error of estimate; $p$, regression ANOVA $p$-values. 

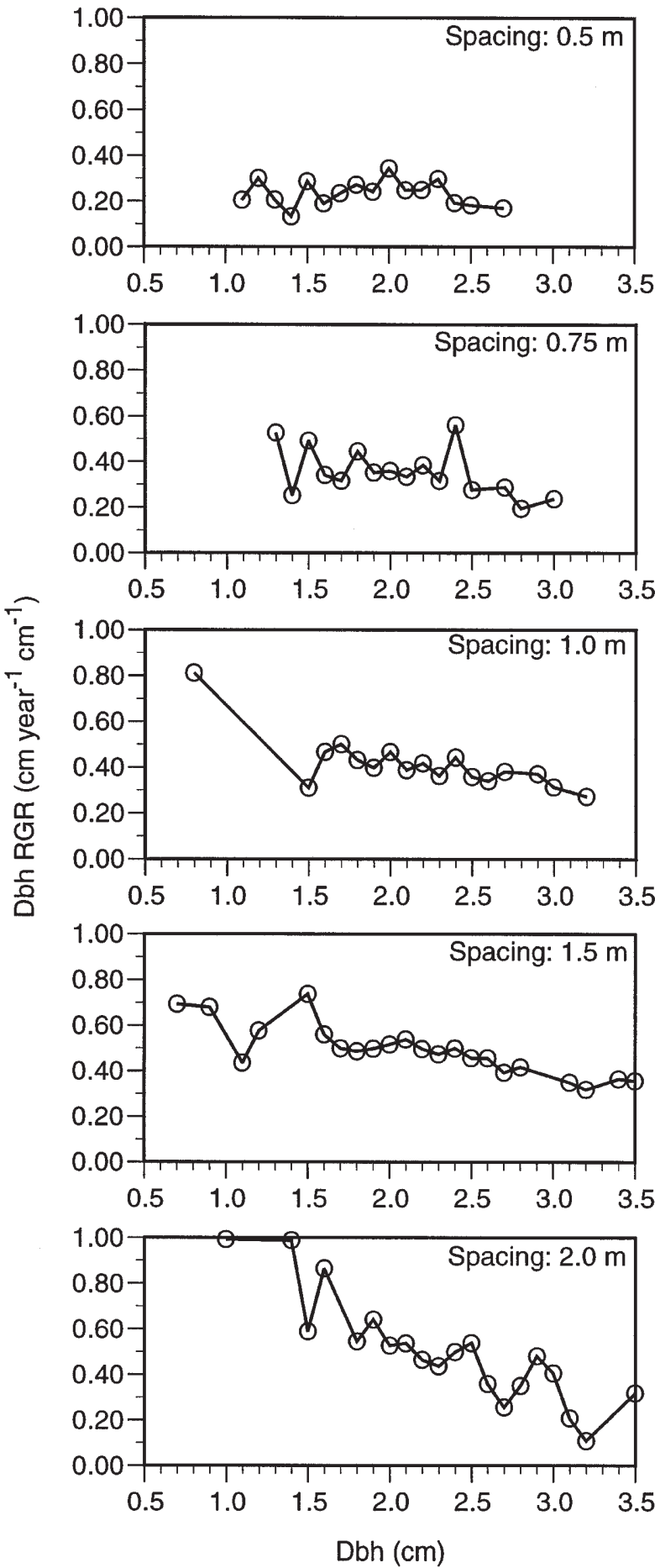

Figure 5. Dbh RGR variation with dbh for wide branch angle trees located in block 1. not necessarily result in increased net $\mathrm{CO}_{2}$ assimilation, even for trees that were not subject to branch interlock. Although Stewart and Hoddinott [60] and Noland et al. [44] have shown that jack pine needles are very sensitive to light conditions, they also indicate that there is a threshold level beyond which the increase in photon flux density does not result in equivalent increase in net $\mathrm{CO}_{2}$ assimilation. For trees that became subject to branch interlock, increased internal shade resulting from a greater horizontal spread of branches (figure 3) may have reduced substantially the amount of light reaching the interior of the crown close to the stem, irrespective of branch angle. However, as the stands were still relatively young, it is premature to ascertain that branch angle will not become a competitive advantage later.

\subsection{Growth and foliage nitrogen}

Changes in the intensity of competitive stress occurred rapidly in these young stands, as suggested by the increased differences in cumulative dbh and crown dimensions among spacings within one year. Dbh RGR and the rate of change in crown width nearly doubled from the closest to the largest spacings and crowns receded by about $20 \%$ within the $0.5 \mathrm{~m}$ and $0.75 \mathrm{~m}$ spacings. This relatively rapid change in competition is not surprising. In studies dealing with the effect of interspecific competition, it was found that the growth of jack pine seedlings was highly sensitive to the presence of both herbaceous and lignified pioneer species, and that this sensitivity was more important in jack pine than in other boreal species such as white pine (Pinus strobus L.) and black and white spruces [5, 33, 39, 40]. Even though height RGR of the $0.5 \mathrm{~m}$ spacing was statistically different from the mean of the $0.75 \mathrm{~m}, 1.0 \mathrm{~m}$ and $1.5 \mathrm{~m}$ spacings, the lower RGR and little differences in cumulative growth in both years are not biologically significant compared with the changes obtained for dbh. The absence of variation in height response under different stand densities was also observed by Bella and DeFranceschi [4], Smith [58] and Morris et al. [38]. Morris et al. [38] reported that it was probably due to the fact that the apical meristems of jack pine are poor photosynthate sinks.

The significant differences among spacings for $\mathrm{N}$ concentrations in needles, branches and stems suggest that belowground competition took place at this early stage of stand development. When compared with standards derived by Swan [62] for jack pine, needle N concentrations in 1990 for the $0.5 \mathrm{~m}, 0.75 \mathrm{~m}$ and $1.0 \mathrm{~m}$ spacings were within the range of low concentrations while the $1.5 \mathrm{~m}$ and $2.0 \mathrm{~m}$ spacings were within the range of critical concentrations. Concentrations in 1991 were within 

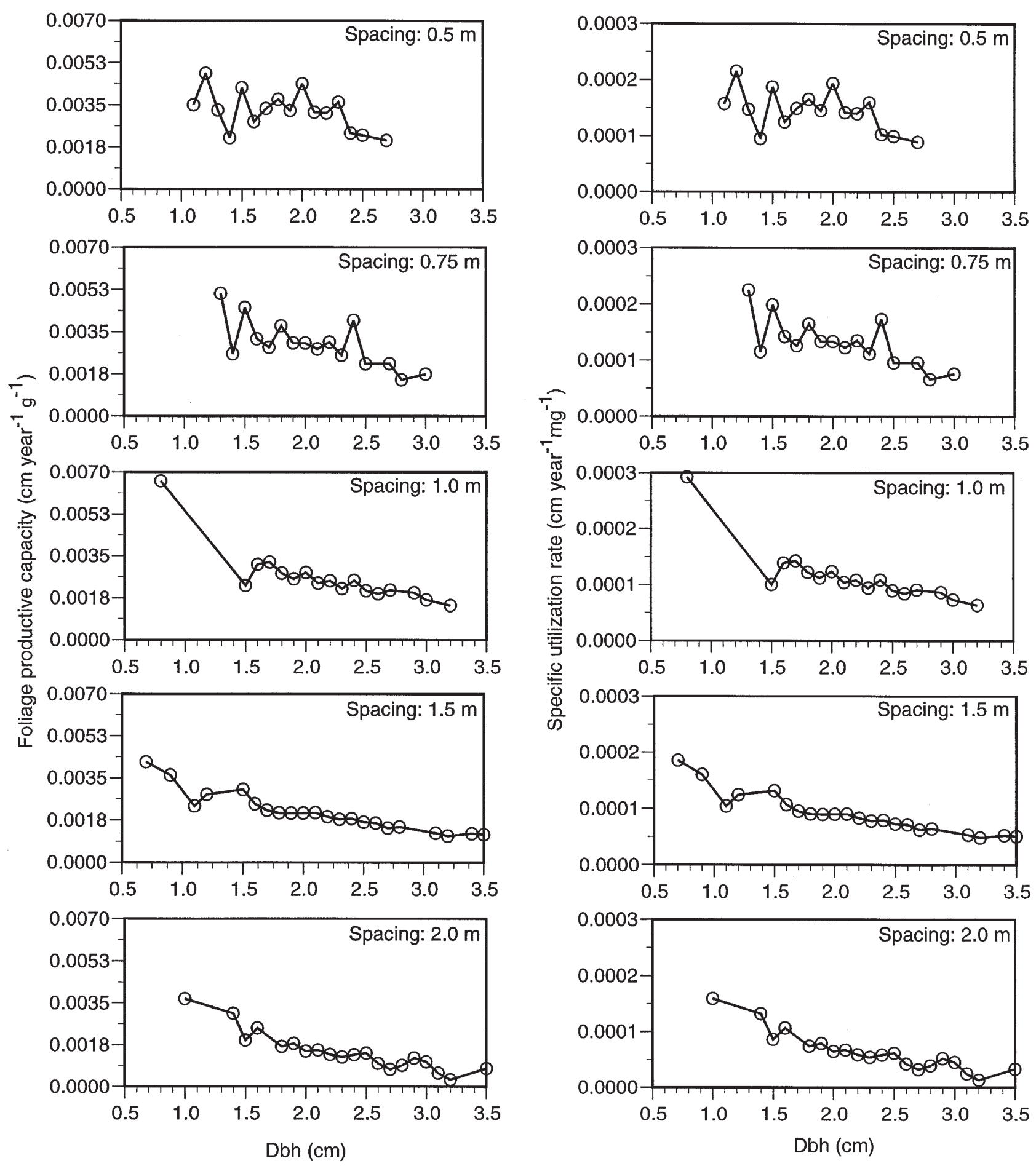

Figure 6. Variation in foliage productive capacity and specific utilization rate with dbh for wide branch angle trees located in block 1 . 
the range of critical concentrations for all spacings. In fertilization trials in jack pine stands of approximately the same age as the trees in this study, Calvert and Armson [6] obtained significant differences in $\mathrm{N}$ concentrations for needles of the same magnitude found in this study. In a similar study undertaken by Sheedy [56], equivalent changes in diameter growth rate were related to equivalent changes in nutrient concentrations.

\subsection{Crown development}

The results obtained for crown width indicate that the reduction in light intensity that occurred before branches began to interlock was sufficient to reduce the photosynthetic rate of jack pine needles, particularly those located in the inferior whorls of the crowns. In 1990, crown width differed significantly among spacings. However, there was no crown overlap, even in the closest spacings, as the horizontal space occupied by individual crowns in the $0.5 \mathrm{~m}$ and $0.75 \mathrm{~m}$ spacings was on average lower than the area available for individual trees in these spacings (figure 3). Also, significant reductions in crown width were obtained in the $0.75 \mathrm{~m}$ and $1.0 \mathrm{~m}$ spacings relative to the $1.5 \mathrm{~m}$ and $2.0 \mathrm{~m}$ spacings well before crowns could overlap with their neighbors. Compared with crown width, however, changes in crown ratio were not substantial, which indicates that, as crown recession took place relatively slowly, needles deep within the canopy were able to photosynthesize under relatively low light intensity. The results for crown width and crown ratio appear contradictory because the former ones suggest that light is a critical factor in young jack pine stands while the latter ones do not. A full explanation of these differences would require detailed physiological measurements in various sections of jack pine crowns in the same competitive conditions. However, it may be hypothesized that jack pine needles are very sensitive to small reductions in light intensity, even like those occurring before crown closure takes place, but that nevertheless they are able to photosynthesize under low light intensity. This is supported by the findings of Logan [31], Stewart and Hoddinott [60] and Noland et al. [44] for jack pine seedlings. Logan [31] observed that growth took place under $13 \%$ of full sunlight, and Stewart and Hoddinott [60] and Noland et al. [44] measured net $\mathrm{CO}_{2}$ assimilation under photon flux density as low as $50 \mu \mathrm{mol} \mathrm{m}{ }^{-2} \mathrm{~s}^{-1}$. However, the last two studies also indicated that the net $\mathrm{CO}_{2}$ assimilation of jack pine needles decreased sharply as light intensity was reduced. For instance, Noland et al. [44] measured net $\mathrm{CO}_{2}$ assimilation rates as low as $2.5 \%$ for seedlings growing under $20 \%$ of full sunlight compared with seedlings under full sunlight.
The increased differences among spacings for NDR from 1990 to 1991 (table III, figure 3) indicate that the efficiency of young jack pine crowns to occupy their aerial growing space was negatively affected by competition and that the intensification of competition accentuated this trend. However, the reduction from 1990 to 1991 in each spacing was not entirely caused by competition, as a decrease in NDR was also obtained in the largest spacings. This occurred because crown width increased while needle biomass decreased (figure 3). The closer the spacing, the slower crown width increased, and the greater needle mortality was. This can be explained by the increase in shade within the crowns as they increased in size $[24,47,57]$. As reported by Stewart and Hoddinott [60] and Noland et al. [44], net $\mathrm{CO}_{2}$ assimilation rate in jack pine needles is very sensitive to small reductions in light intensity. As crowns grew bigger, needles inside the crowns closer to the stem probably disappeared because the quantity of light was insufficient to maintain an adequate equilibrium between photosynthesis and respiration. The effect of self-shading probably accentuated as spacing decreased because of the presence of relatively close neighboring crowns. The negative relationship between NDR and CSR agrees with the findings of Kuuluvainen [24] for Norway spruce (Picea abies (L.) Karst.) and of Larocque and Marshall [28] for red pine and suggests that, despite the decrease in NDR with the increase in competition, needles of trees with narrow crowns within a given spacing occupied their growing space more efficiently than trees with larger crowns. This relationship was more critical for wide branch angle trees probably because the crowns were slightly larger in 1991 than the crowns of acute branch angle trees.

Similarly to NDR, the decrease in LWR from 1990 to 1991 within each spacing was probably caused in part by internal shading within crowns before branch interlock. However, the accentuation of significant differences among spacings from 1990 to 1991 indicates that competition affected dry matter allocation, as the proportion of photosynthesizing tissue relative to the proportion of respiring tissue decreased. The regression analysis of LWR as a function of CR and needle $\mathrm{N}$ concentration highlighted the importance of both above- and belowground competition. However, the greater Beta coefficients for crown ratio indicate that the intensity of crown recession had a greater effect than needle nitrogen concentration on dry matter allocation, which suggests that aboveground competition was more important than belowground competition. Both branch types did not differ much in the relative contribution of crown ratio and needle nitrogen concentration to dry matter accumulation. 


\subsection{Growth efficiency variation with tree size}

The patterns of variation of dbh RGR with tree size, that is, the relatively small decrease in the two closest spacings and the sharp decrease in the three largest spacings, are similar to two of the trends observed by Perry [47] and Larocque and Marshall [27]: (1) decrease in RGR with increase in tree size in the absence of severe competition, and (2) relatively little variation in RGR with tree size at the onset of severe competition. The first trend characterizes the $1.0 \mathrm{~m}, 1.5 \mathrm{~m}$ and $2.0 \mathrm{~m}$ spacings and the second one the $0.5 \mathrm{~m}$ and $0.75 \mathrm{~m}$ spacings. However, contrary to the findings of Perry [47] for Douglas-fir and Larocque and Marshall [27] for red pine, the reversal of the trend as the intensity of competitive stress increased was not obtained, which suggests that jack pine responds slower than Douglas-fir and red pine to changes in growth efficiency as the intensity of competition increases. The patterns similar to RGR that were obtained for FPC and SUR within every spacing imply that small trees were more efficient producers of stemwood per unit of photosynthetic tissue and per unit of nitrogen uptaken than large trees in the absence of severe competition, and, therefore, support the hypothesis of change in efficiency in relation to the use of resources by trees under variable intensities of competition.

The decrease in dbh RGR with increase in tree size indicates that small trees are more efficient producers of stemwood than large trees in the absence of competition [47]. According to Perry [47], when this occurs, large trees with bigger crowns are less efficient to produce stemwood than small trees because of their greater maintenance respiration needs associated with larger roots, stems and branches, even though they have a greater photosynthetic productivity. Kaufmann and Ryan [22] and Roberts et al. [51] reached the same conclusion after observing a decline in leaf area efficiency, which is similar in concept to FPC derived in the present study, with increase in crown leaf area. The hypothesis of greater respiration needs for larger trees is supported by the study of Ryan [52] in which sapwood volume for three subalpine conifers was estimated. Reed et al. [50] suggested that canopy stratification may also explain the occurrence of these patterns. In stands consisting of uniformly distributed young trees, there is little canopy stratification and light conditions do not differ much among trees. In these conditions, which occur in stands before the onset of competition, trees with lower leaf area are more efficient producers of stemwood. As canopy stratification takes place when competition begins, individual tree light conditions increasingly differ, which affects the pattern of leaf area distribution.

\section{CONCLUSION}

The results of this study highlighted the high sensitivity of young jack pine to competition. Crown development was negatively affected by the presence of neighboring crowns well before branch interlock, and differences in crown recession rate, needle density ratio and dry matter allocation among spacings increased significantly within one year. However, differences in needle nitrogen concentration among spacings were relatively less pronounced. Branch angle trait did not constitute a significant advantage for crown development and stem growth. The measures of growth efficiency based on RGR and on the ratios of dbh increment to needle biomass and nitrogen content can be used to evaluate the competitive status of stands. In particular, the last two ratios express the changes in efficiency in relation to the photosynthetic component of the tree and nitrogen uptake rate. Thus, they can be used as reliable tools to study, in more depth, stand dynamics in the light of different levels of competitive stress.

Acknowledgements: The assistance of L. Clark, B. Frederick, F. McBain, H. Markussen, E. Turcotte and I. Miller, formerly of the Petawawa National Forestry Institute, with field work and laboratory analysis is greatly appreciated. Sincere thanks are also extended to Drs. A.L. D'Aoust and G. Robitaille, Mr. R. Boutin and Ms. M. Bernier-Cardou, of the Laurentian Forestry Centre, and to Dr. J.-P. Carpentier, of the Quebec Ministry of Natural Resources, for helpful comments in the review of the manuscript and advice on statistical analyses.

\section{REFERENCES}

[1] Adams G.W., Morgenstern E.K., Multiple-trait selection in jack pine, Can. J. For. Res. 21 (1991) 439-445.

[2] Beaudoin R., Variabilité phénotypique et corrélations juvéniles-adultes chez les pins gris de la provenance "Briand", Mémoire de recherche forestière $\mathrm{n}^{\circ} 109$, Direction de la Recherche et du Développement, Ministère de l'Énergie et des Ressources, Québec, 1993.

[3] Bella I.E., Spacing effects 20 years after planting three conifers in Manitoba, Forest Management Note No. 39, Northern Forestry Centre, Can. For. Serv., 1986.

[4] Bella I.E., DeFranceschi J.P., Spacing effects 15 years after planting three conifers in Manitoba, Inf. Rep. NOR-X223, Northern Forest Research Centre, Can. For. Serv., 1980.

[5] Brand D.G., The establishment of boreal and sub-boreal conifer plantations: an integrated analysis of environmental conditions and seedling growth, For. Sci. 37 (1991) 68-100. 
[6] Calvert R.F., Armson K.A., The growth response of young jack pine to nitrogen and phosphorus, Can. J. For. Res. 5 (1980) 529-538.

[7] Cannell M.G.R., Rothery P., Ford E.D., Competition within stands of Picea sitchensis and Pinus contorta, Ann. Bot. 53(1984) 349-362.

[8] Ceulemans R., Stettler R.F., Hinckley T.M., Isebrands J.G., Heilman, P.E., Crown architecture of Populus clones as determined by branch orientation and branch characteristics, Tree Physiol. 7 (1990) 157-167.

[9] Colin F., Houllier F., Branchiness of Norway spruce in northeastern France: predicting the main crown characteristics from usual tree measurements, Ann. Sci. For. 49 (1992) 511-538.

[10] Erickson R.O., Modeling of plant growth, Annu. Rev. Plant Physiol. 27 (1976) 407-434.

[11] Farrar R.M., Jr. 1984. Crown ratio used as a surrogate for form in a volume equation for natural longleaf pine stems, in: Shoulders, E., (Ed.), Proceedings of the Third Biennial Southern Silvicultural Research Conference, Atlanta, GA, November 7-8, 1984, Gen. Tech. Rep. SO-54, Southern For. Exp. Stn., USDA Forest Service, New Orleans, Louisiana, 1984, pp. 429-435.

[12] Fitter A.H., Hay R.K.M., Environmental Physiology of Plants, 2nd ed., Academic Press, Toronto, 1987.

[13] Ford E.D., An ecological basis for predicting the growth and stability of plantation forests, in: Ford E.D., Malcolm D.C., Atterson J. (Eds.), The Ecology of Even-aged Forest Plantations, Institute of Terrestrial Ecology, Cambridge, United Kingdom, 1979, pp. 147-174.

[14] Ford E.D., The dynamics of plantation growth, in: Bowen G.D., Nambiar E.K.S. (Eds.), Nutrition of Plantation Forests, Academic Press, London, 1984, pp. 17-52.

[15] Gleeson S.K., Tilman D.. Plant allocation, growth rate and successional status, Funct. Ecol. 8 (1994) 543-550.

[16] Goldberg D.E. 1990. Components of resource competition in plant communities, in: Grace J.B., Tilman D. (Eds.), Perspectives on Plant Competition, Academic Press, New York, pp. 27-49.

[17] Harper J.L., Population Biology of Plants, Academic Press, London, 1977.

[18] Hunt R., Plant Growth Curves: the Functional Approach to Plant Growth Analysis, Edward Arnold (Publishers) Limited, London, 1982.

[19] Hunt R., Basic Growth Analysis, Unwin Hyman Ltd, London, 1990.

[20] Janas P.S., Brand D.G., Comparative growth and development of planted and natural stands of jack pine, For. Chron. 64 (1988) 320-328.

[21] Kalra Y.P., Maynard D.C., Methods manual for forest soil and plant analysis, Inf. Rep. NOR-X-319, Northern Forestry Centre, Forestry Canada, 1991.

[22] Kaufmann M.R., Ryan M.G., Physiographic, stand, and environmental effects on individual tree growth and growth efficiency in subalpine forests, Tree Physiol. 2 (1986) 47-59.
[23] Kaufmann M.R., Watkins R.K., Characteristics of high- and low-vigor lodgepole pine trees in old-growth stands, Tree Physiol. 7 (1990) 239-246.

[24] Kuuluvainen T., Crown architecture and stemwood production in Norway spruce (Picea abies (L.) Karst.), Tree Physiol. 4 (1988) 337-346.

[25] Kuuluvainen T. 1991. The effect of two growth forms of Norway spruce on stand development and radiation interception: a model analysis. Trees (Berl.) 5: 171-179.

[26] Kuuluvainen T., Pukkala T., Effect of crown shape and tree distribution on the spatial distribution of shade, Agric. For. Meteorol. 40 (1987) 215-231.

[27] Larocque G.R., Marshall P.L., Evaluating the impact of competition using relative growth rate in red pine (Pinus resinosa Ait.) stands, For. Ecol. Manag. 58 (1993) 65-83.

[28] Larocque G.R., Marshall P.L., Crown development in red pine stands. I. Absolute and relative growth measures, Can. J. For. Res. 24 (1994a) 762-774.

[29] Larocque G.R., Marshall P.L., Crown development in red pine stands. II. Relationships with stem growth, Can. J. For. Res. 24 (1994b) 775-784.

[30] LeBlanc P.A., Towill W.D. 1989. Can jack pine productivity in north central Ontario be predicted using multiple regression soil-site equations? Technical Report No.33, Northwestern Ontario Forest Technology Development Unit, Ontario Ministry of Natural Resources, Thunder Bay.

[31] Logan K.T., Growth of tree seedlings as affected by light intensity. II. Red pine, white pine, jack pine and eastern larch, Publication No. 1160. Department of Forestry of Canada, 1966.

[32] MacDonald G.B., Morris D.M., Marshall P.L., Assessing components of competition indices for young boreal plantations, Can. J. For. Res. 20 (1990) 1060-1068.

[33] MacDonald G.B., Weetman G.F., Functional growth analysis of conifer seedling responses to competing vegetation, For. Chron. 69 (1993) 64-70.

[34] Magnussen S., Smith V.G., Yeatman C.W., Tree size, biomass, and volume growth of twelve 34-year-old Ontario jack pine provenances, Can. J. For. Res. 15 (1985) 1129-1136.

[35] Magnussen S., Yeatman C.W., Early testing of jack pine. II. Variance and repeatability of stem and branch characters, Can. J. For. Res. 17 (1987) 460-465.

[36] Margolis H.A., Brand D.G., An ecophysiological basis for understanding plantation establishment, Can. J. For. Res. 20 (1990) 375-390.

[37] Morris D.M., Forslund R.R., A field-oriented competition index for young jack pine plantations and a computerized decision tool for vegetation management, New For. 5 (1991) 93-107.

[38] Morris D.M., Bowling C., Hills S.C., Growth and form responses to pre-commercial thinning regimes in aerially seeded jack pine stands: 5th year results, For. Chron. 70 (1994) 780-787.

[39] Morris D.M., MacDonald G.B., McClain K.M., Evaluation of morphological attributes as response variables 
to perennial competition for 4-year-old black spruce and jack pine seedlings, Can. J. For. Res. 20 (1990) 1696-1703.

[40] Morris D.M., MacDonald G.B., Development of a competition index for young conifer plantations established on boreal mixedwood sites, For. Chron. 67 (1991) 403-410.

[41] Morris D.M., Parker W.H., Variable-quality form in mature jack pine stands: quantification and relationship with environmental factors, Can. J. For. Res. 22 (1992) 279-289.

[42] Morrison I.K., Foster N.W., Effect of nitrogen, phosphorus and magnesium fertilizers on growth of a semimature jack pine forest, northwestern Ontario, For. Chron. 71 (1995) 422-425.

[43] Munson A.D., Timmer V.R., Soil nitrogen dynamics and nutrition of pine following silvicultural treatments in boreal and Great Lakes-St. Lawrence plantations, For. Ecol. Manag. 76 (1995) 169-179.

[44] Noland T.L., Mohammed G.H., Scott M., The dependence of root growth potential on light level, photosynthetic rate, and root starch content in jack pine seedlings, New For. 13 (1997) 105-119.

[45] Norgren O. Growth analysis of Scots pine and lodgepole pine seedlings, For. Ecol. Manag. 86 (1996) 15-26.

[46] Payandeh, B., Sutton R.F., Modeling early plantation performance: identification of critical factors, Scand. J. For. Res. 4 (1989) 75-86.

[47] Perry D.A., The competition process in forest stands, in: Cannell M.G.R., Jackson J.E. (Eds.), Attributes of Trees as Crop Plants, Institute of Terrestrial Ecology, Huntingdon, England, 1985, pp. 481-506.

[48] Pöykkö V.T., Pulkkinen P.O., Characteristics of normal-crowned and pendula spruce (Picea abies (L.) Karst.) examined with reference to the definition of a crop tree ideotype, Tree Physiol. 7 (1990) 201-207.

[49] Radosevich S.R., Osteryoung K.,. Principles governing plant-environment interactions, in: Walstad J.D., Kuck P.J. (Eds.), Forest Vegetation Management for Conifer Production, Wiley, New York, 1987, pp. 105-156.

[50] Reed D.D., Mroz G.D., Liechty H.O., Jones E.A., Cattelino P.J., Balster N.J., Zhang Y., Above- and belowground biomass of precompetitive red pine in northern Michigan, Can. J. For. Res. 25 (1995) 1064-1069.

[51] Roberts S.D., Long J.N., Smith F.W., Canopy stratification and leaf area efficiency: a conceptualization, For. Ecol. Manage. 60 (1993) 143-156.

[52] Ryan M.G., Sapwood volume for three subalpine conifers: predictive equations and ecological implications, Can. J. For. Res. 19 (1989) 1397-1401.
[53] SAS Institute Inc., SAS/STAT ${ }^{\circledR}$ User's Guide, Version 6, Fourth Edition, Vol. 2, SAS Institute Inc., Cary, NC, 1989.

[54] Schmidt M.G., Carmean W.H.., Jack pine site quality in relation to soil and topography in north central Ontario, Can. J. For. Res. 18 (1987) 297-305.

[55] Schmitt J., Eccleston J., Ehrhardt D.W., Dominance and suppression, size-dependent growth and self-thinning in a natural Impatiens capensis population. J. Ecol. 75 (1987) 651-665.

[56] Sheedy G., Essai de fertilisation dans une jeune plantation de pin gris. Résultats de cinq ans, mémoire $\mathrm{n}^{\circ} 83$, Service de la recherche, Min. de l'Énergie et des Ressources, Gouv. du Québec, 1982.

[57] Sheppard L.J., Ford E.D., Genetic and environmental control of crown development in Picea sitchensis and its relation to stem wood production, Tree Physiol. 1 (1986) 341-352.

[58] Smith C.R.. Precommercial thinning in jack pine with particular reference to experiments in northeastern Ontario. In: Smith C.R., Brown G. (Eds.), Jack Pine Symposium, 18-20 Oct. 1983, Timmins, Ont., COJFRC Symposium Proceedings O-P-12, Great Lakes For. Res. Centre, Can. For. Serv., Sault Ste. Marie, Ontario, 1984, pp. 122-130.

[59] Sprinz P.T., Burkhart H.E., Relationships between tree crown, stem, and stand characteristics in unthinned loblolly pine plantations, Can. J. For. Res. 17 (1987) 534-538.

[60] Stewart J.D., Hoddinott J., Photosynthetic acclimation to elevated atmospheric carbon dioxide and UV irradiation in Pinus banksiana, Physiol. Plant. 88 (1993) 493-500.

[61] St-Pierre H., Gagnon R., Bellefleur P., Régénération après feu de l'épinette noire (Picea mariana) et du pin gris (Pinus banksiana) dans la forêt boréale, Québec, Can. J. For. Res. 22 (1992) 474-481.

[62] Swan H.S.D., Relationship between nutrient supply, growth and nutrient concentrations in the foliage of black spruce and jack pine. Woodlands Pap. No. 19, Pulp Pap. Res. Inst. Can., Montréal, 1970.

[63] Wang Y.P., Jarvis P.G., Influence of crown structural properties on PAR absorption, photosynthesis, and transpiration in Sitka spruce: application of a model (MAESTRO), Tree Physiol. 7 (1990) 297-316.

[64] Waring R.H., Thies W.G., Muscato D., Stem growth per unit of leaf area: a measure of tree vigor, For. Sci. 26 (1980) 112-117.

[65] Waring R.H., Newman K., Bell J.,. Efficiency of tree crowns and stemwood production at different canopy leaf densities, Forestry 54 (1981) 129-137. 